ISSN: 2338-4328 (Print), ISSN: 2686-2646 (Online)

Available online at: https://sultanist.ac.id/index.php/sultanist

\title{
ANALISIS KETERSEDIAAN DAN KELAYAKAN SARANA PRASARANA PERKULIAHAN DI PERGURUAN TINGGI
}

\author{
Ibnu Hasan Karbila ${ }^{1}$ *, Usman ${ }^{2)}$ \\ ${ }^{1}$ Perencana Anggaran, IAIN Palangka Raya, Kalimantan Tengah, Indonesia. \\ ${ }^{2}$ Pustakawan, IAIN Palangka Raya, Kalimantan Tengah, Indonesia. \\ *E-mail: '1ibnu.hasan06@yahoo.com, 22usmansagssmhi@gmail.com
}

\begin{abstract}
Abstrak
Kualitas pendidikan perguruan tinggi tidak lepas dari tersedianya sarana dan prasarana yang menjadi standar dari perguruan tinggi, IAIN Palangka Raya hampir setiap tahun melakukan pengadaan sarana prasarana, namun kegiatan ini belum didasari dengan analisis kebutuhan dan evaluasi terhadap sarana dan prasarana. Tujuan penelitian ini adalah untuk mengetahui ketersediaan dan kelayakan sarana dan prasarana dari aspek persepsi civitas akademika di IAIN Palangka Raya. Pendekatan yang digunakan dalam penelitian ini adalah pendekatan kualitatif. Subjek dalam penelitian ini adalah civitas akademika IAIN Palangka Raya. Sampel diambil secara acak yang teridiri dari tenaga pendidik, tenaga kependidikan, mahasiswa dan alumni. Pengumpulan data dilakukan dengan metode angket, observasi, dan dokumentasi. Data dianalisis dengan metode deskriptif kualitatif. Hasil penelitian menujukkan ketersediaan sarana prasarana perkuliahan di IAIN Palangka Raya telah memenuhi standar dari permenristikdikti nomor 44 tahun 2015 tentang standar sarana prasarana pendidikan pasal 32-36. Namun IAIN Palangka Raya belum memenuhi ketentuan standar yang diatur dalam pasal 37 tentang standar sarana prasarana yang dapat diakses oleh disabilitas. Kelayakan sarana prasarana menurut civitas akademika IAIN Palangka Raya terkatogori layak dan sangat layak sebesar 79,56\%. Hasil ini menujukkan kondisi sarana dan prasarana di IAIN Palangka Raya layak digunakan sesuai dengan standar kegiatan pembelajaran di perguruan tinggi.
\end{abstract}

Kata kunci: Analisis Ketersediaan, Analisis Kelayakan, Sarana Prasarana

\section{ANALYSIS OF AVAILABILITY AND FEASIBILITY OF EDUCATION FACILITIES IN COLLEGE EDUCATION}

\begin{abstract}
The quality of tertiary education cannot be separated from the availability of facilities and infrastructure that become the standards of higher education. IAIN Palangka Raya almost every year procures infrastructure, but this activity has not been based on a needs analysis and evaluation of facilities and infrastructure. The purpose of this study was to determine the availability and feasibility of facilities and infrastructure from the perceptual aspects of the academic community at IAIN Palangka Raya. The approach used in this study is a qualitative approach. The subjects in this study were the academic community of IAIN Palangka Raya. Samples were taken randomly which consisted of educators, educational staff, students and alumni. Data collection was carried out by using a questionnaire method, observation, and documentation. Data were analyzed using descriptive qualitative methods. The results show that the availability of lecture infrastructure at IAIN Palangka Raya has met the standards of Permenristikdikti number 44 of 2015 concerning the standard of educational infrastructure, articles 32-36. However, IAIN Palangka Raya has not fulfilled the standard provisions stipulated in Article 37 concerning the standard of infrastructure accessible for persons with disabilities. The feasibility of infrastructure according to the IAIN Palangka Raya academic community is categorized as feasible and very feasible at $79.56 \%$. These results indicate that the condition of facilities and infrastructure at IAIN Palangka Raya is suitable for use in accordance with the standards of learning activities in higher education.
\end{abstract}

Keywords: analysis of availability, analysis of feasibility, education facilities 


\section{SULTANIST: Jurnal Manajemen dan Keuangan, Vol 9 (1), Juni 2021}

\section{PENDAHULUAN}

Pelaksanaan Tri Dharama Perguruan tinggi harus didukung oleh dua komponen yaitu sumber daya manusia dan sarana prasarana (sarpras) yang memadai. Komponen sarpras menjadi hal yang sangat penting dalam terlaksanya suatu kegiatan. Dalam Undang-Undang Republik Indonesia No 20 tahun 2003 tentang sistem pendidikan Nasional dalam Bab XII pasal 45 disebutkan "Setiap satuan pendidikan formal dan nonformal menyediakan sarana dan prasarana yang memenuhi yang memenuhi keperluan pendidikan sesuai dengan pertumbuhan dan perkembangan potensi fisik, kecerdasan intelektual, sosial, emosional, dan kewajiban peserta didik (Undang-Undang RI Tahun 2003). Hal ini menunjukkan perhatian pemerintah sangat serius terhadap kebutuhan sarana prasarana pendidikan.

Kualitas pendidikan perguruan tinggi tidak lepas dari tersedianya sarana dan prasarana yang menjadi standar dari perguruan tinggi tersebut. Keberadaan Sarana dan prasarana sangat mempengaruhi kemampuan mahasiswa dalam belajar yang berpengruh terhadap output lulusan dalam bersaing di dunia lapangan pekerjaan. Oleh karena itu pemerintah melalui BAN-PT memasukkan kriteria pembiayaan, sarana dan prasarana, serta sistem informasi dalam standar borang penilaian akreditasi. Legalitas penyelenggaraan pendidikan menjadi aspek penting untuk diperhatikan semua perguruan tinggi. Status akreditasi dalam suatu perguruan tinggi mencerminkan kualitas lembaga pendidikan tinggi dari aspek komitmen program studi terhadap kapasitas institusional dan efektivitas program pendidikan. Keberadaan sarana prasarana dalam standar borang menunjukkan bahwa peranan sarana dan prasarana sangat penting dalam menunjang kualitas akademik dalam suatu perguruan tinggi

Kementrian Riset, Teknologi dan Pendidikan Tinggi Indonesia mengatur tentang Satndar Nasional Pendidikan Tinggi. Permenristekdikti no 44 tahun 2015 mengatur tentang standar sarana dan prasarana pembelajaran pada bagian ke tujuh pasal 31 sampai 37. Peraturan tersebut menjadi dasar pentingnya pengelolaan sarana dan prasarana di perguruan tinggi guna menjamin mutu pendidikan tinggi.

IAIN Palangka Raya merupakan salah satu Perguruan Tinggi Islam terbesar yang ada di Kalimantan Tengah, keberadaannya sebagai intansi vertikal dinaungi oleh kementerian Agama RI. Rencana Strategis IAIN Palangka Raya sebagai perguruan tinggi selalu selaras dengan Kementerian Agama yang mencakup berbagai aspek yang mendukung terlaksannya Tri Dharma Perguruan Tinggi yaitu pendidikan, Penelitian dan Pengabdian kepada Masyarakat. Renstra tersebut Selanjutnya dijabarkan dalam Rencana Kerja Tahunan (RKT) yang dilaksanakan Oleh IAIN Palangka Raya melalui Fakultas, Pascasarjana dan Unit Lembaga dalam berbagai kegiatan tahunan serta berisi informasi mengenai tingkat target kinerja berupa Output dan/atau Outcome yang ingin diwujudkan.

Setiap Fakultas/Pascasarjana/Unit lembaga setiap tahunnya mendapatkan jatah pengadaan sarpras dari Unit Layanan Pengadaan. Pengadaan dilakukan dengan merespon berbagai usulan dari unit terkait sebagai dasar pengadaannya. Pengadaan tersebut sifatnya terbatas, mengingat 


\section{SULTANIST: Jurnal Manajemen dan Keuangan, Vol 9 (1), Juni 2021}

anggaran yang diberikan oleh Ditjen Pendis ke Seluruh PTKIN tidak terlalu signifikan besarnya. Dengan anggaran seadanya setiap tahun IAIN Palangka Raya harus bisa memilih prioritas utama dalam pengadaan dengan lebih mementingkan kebutuhan daripada yang sifatnya sebagai pemenuhan keinginan belaka. Sehingga sarana prasarana yang ada dapat berdaya guna secara efektif dan efesien serta memenuhi standar sarana prasarana perguruan tinggi yang ditentukan.

IAIN Palangka Raya sebagai lembaga penyelenggaran pendidikan beberapa tahun terakhir telah mengadakan pengadaan sarana prasarana perkuliahan dan perkantoran. Pengadaan dilaksanakan secara $E$ Catalouge, dimana pengadaan seperti ini dapat memilih secara langsung spesifikasi barang yang hendak diadakan, baik barang elektronik maupun non elektronik. Namun pengadaan sarana dan prasarana tersebut belum pernah dilakukan analisis kesesuaian antara ketersediaan dan kebutuhan serta kelayakannya bagi civitas akademika IAIN Palangka Raya.

Berdasarkan latar belakang diatas perlu dilakukan analisis kebutuhan dan kelayakan serta ketersdiaan terhadap sarana dan prasaana di IAIN Palangka Raya. Hal ini akan memberikan informasi terkait sarana prasarana kegiatan belajar mengajar dan pelayanan akademik mahasiswa IAIN palangka Raya kepada Rektor IAIN Palangka Raya, dalam hal ini Unit Layanan Pengadaan (ULP). Hasil penelitian ini dapat menjadi bahan pertimbangan dalam pemetaan pengadaan sarpras tahun anggaran 2021 agar sesuai dengan tugas pokok dan fungsi dari masing-masing unit dan lembaga.

\section{LANDASAN TEORI}

$\begin{array}{cccc}\text { Sarana } & \text { dan } & \text { prasarana } & \text { yang } \\ \text { dimanfaatkan } & \text { dalam } & \text { perguruan } & \text { tinggi }\end{array}$ merupakan salah satu indikator sebagai ukuran tingkat baik atau buruknya layanan yang diberikan instansi kepada masyarakat. Pemanfaatan sarana prasarana yang baik harus disesuaikan dengan kebutuhan, terdapat empat tujuan penggunaan sarana prasarana yang efektif, yaitu: tercapainya tujuan; relevan penggunaan antarmedia dan pembahasan materi; sarana prasarana yang tersedia; dan karakteristik siswa (Mustari, 2014).

Penggunaan yang tepat pada sarana dan prasarana merupakan bentuk penunjang dan dukungan tercapainya proses perkuliahan dan layanan akademik dalam suatu instansi, hingga harapan untuk menjadi sebuah perguruan tinggi yang baik dan terus melakukan perbaikan dapat memenuhi kebutuhan dan keinginan dari masyarakat, baik internal mau pun eksternal. Standar minimal sarana dan prasarana perguruan tinggi mengacu pada rancangan standar sarana dan prasarana pendidikan tinggi yang ditetapkan melalui Peraturan Menteri Riset, Teknologi, dan Pendidikan Tinggi Republik Indonesia nomor 44 tahun 2015 tentang standar nasional pendidikan tinggi. Standar sarana dan prasarana pembelajaran merupakan kriteria minimal tentang sarana dan prasarana sesuai dengan kebutuhan isi dan proses pembelajaran dalam rangka pemenuhan capaian pembelajaran lulusan. Standar sarana pembelajaran sebagaimana dimaksud paling sedikit terdiri atas: perabot; peralatan pendidikan; media pendidikan; buku, buku elektronik, dan repositori; sarana teknologi informasi dan komunikasi; instrumentasi eksperimen; sarana olahraga; sarana berkesenian; sarana fasilitas umum; bahan 


\section{SULTANIST: Jurnal Manajemen dan Keuangan, Vol 9 (1), Juni 2021}

habis pakai; dan sarana pemeliharaan, keselamatan, dan keamanan.

Adapun jumlah, jenis, dan spesifikasi sarana sebagaimana dimaksud diatas tidak memiliki standar yang baku dalam pelaksanaannya, namun ditetapkan berdasarkan rasio penggunaan sarana sesuai dengan karakteristik metode dan bentuk pembelajaran, serta harus menjamin terselenggaranya proses pembelajaran dan pelayanan administrasi akademik. Sedangkan Standar prasarana pembelajaran bagi pendidikan tinggi berdasarkan Peraturan Menteri Riset, Teknologi, dan Pendidikan Tinggi Republik Indonesia nomor 44 tahun 2015 paling sedikit terdiri atas: lahan; ruang kelas; perpustakaan; laboratorium/studio/bengkel kerja/unit produksi; tempat berolahraga; ruang untuk berkesenian; ruang unit kegiatan mahasiswa; ruang pimpinan perguruan tinggi; ruang dosen; ruang tata usaha; dan fasilitas umum yang meliputi: jalan, air; listrik; jaringan komunikasi suara dan data.

Sesuai dengan peraturan menteri yang menangani urusan pemerintahan di bidang pekerjaan umum, Bangunan gedung yang ada pada suatu pendidikan tinggi harus memiliki standar kualitas minimal kelas A atau setara. Bangunan tersebut harus memenuhi persyaratan keselamatan, kesehatan, kenyamanan, dan keamanan, serta dilengkapi dengan instalasi listrik yang berdaya memadai dan instalasi, baik limbah domestik maupun limbah khusus, apabila diperlukan.

Akses umum bagi penyandang disabilitas juga menjadi perhatian serius bagi pemnerintah Negara Republik Indonesia tak terkecuali dibidang pendidikan. Hal ini sesuai dengan adanya Convention On The Rights of
Persons With Disabillities, pada 2011 lalu yang tertuamg dalam Undang-undang No 19 Tahun 2011 tentang Pengesahan Convention on the Rights of Persons with Disabilities (Konvensi Hak-hak Penyandang Disabilitas). Indonesia merupakan negara ke-107 yang meratifikasi konvensi tersebut. Dalam konvensi tersebut diatur hak-hak penyandang disabilitas yang harus dipatuhi oleh negara pihak, hak-hak tersebut meliputi: hak untuk hidup; hak perlindungan dalam situasi yang penuh resiko dan darurat; hak pengakuan yang setara di depan hukum; hak untuk bebas dan aman; hak bebas dari rasa sakit dan perlakuan yang kejam; hak bebas dari eksploitasi, kekerasan dan pelecehan; hak penghormatan terhadap privasi, bebas untuk hidup mandiri; hak untuk mengakses mobilitas personal, akses informasi; hak penghormatan untuk memiliki rumah dan keluarga, berpartisipasi dalam kehidupan publik dan politik, kebebasan berekpresi; hak ekonomi; hak sosial dan budaya lainnya

Untuk menjamin pemenuhan hak penyandang disabilitas, pemerintah telah menerbitkan Undang-undang Nomor 18 tahun 2016 tentang penyandang disabilitas. Undang-undang tersebut tidak saja menjadi payung hukum bagi penyandang disabilitas, tetapi juga merupakan jaminan agar kaum disablitas terhindar dari segala bentuk ketidakadilan dan diskriminasi. Secara garis besar, Undang-Undang Penyandang Disabilitas mengatur mengenai pelaksanaan penghormatan, pelindungan, dan pemenuhan hak penyandang disabilitas. Dengan adanya undang-undang tersebut, makapenyandang disabilitas akan lebih kuat dalam memperoleh hak dan kesempatan dalam berbagai kehidupan, mulai dari hak hidup, hak mendapatkan 


\section{SULTANIST: Jurnal Manajemen dan Keuangan, Vol 9 (1), Juni 2021}

pekerjaan yang layak, pendidikan yang lebih baik dan kemudahan mengakses fasilitas umum.

Terkait dengan pendidikan dan fasilitas umum bagi penyandang disabilitas, maka lembaga pendidikan selayaknya juga memenuhi segala kriteria pendidikan dan fasilitas bagi penyandang disabilitas. Pendidikan yang dimaksud dalam undangundang tersebut menyangkut pendidikan dasar, menengah hingga pendidikan tinggi. Dalam Permenristek Dikti nomor 44 Tahun 2015 pasal 37 disebutkan bahwa perguruan tinggi harus menyediakan sarana dan prasarana yang dapat diakses oleh mahasiswa yang berkebutuhan khusus yang meliputi: Pelabelan dengan tulisan Braille dan informasi dalam bentuk suara; Lerengan (ramp) untuk pengguna kursi roda; Jalur pemandu (guiding block) di jalan atau koridor di lingkungan kampus; Peta/denah kampus atau gedung dalam bentuk peta/denah timbul; dan Toilet atau kamar mandi untuk pengguna kursi roda.

\section{METODE}

Jenis penelitian adalah penelitian kualitatif deskriptif. Subjek penelitian adalah civitas akademika di IAIN Palangka Raya yang menggunakan dan menangani hal-hal terkait sarana dan parasarana. Sampel diambil secara acak yang terdiri dari tenaga pendidik, tenaga kependidikan, mahasiswa dan alumni IAIN Palangka Raya. Pengambilan data terkait sarana dan prasarana dilakukan melalui teknik observasi, pengisian angket, wawancara dan dokumentasi. Observasi dilakukan untuk meninjau ketersediaan dan kelayakan sarana dan prasarana perkuliahan. Teknik pengambilan data melalui pengisian angket kuesioner dilakukan terhadap tenaga pendidik, tenaga kependidikan, mahasiswa dan alumni untuk memperoleh informasi ketersediaan dan kelayakan sarana dan prasasrana di IAIN Palangak Raya. Data dianalisis secara deskriptif kualitatif.

\section{HASIL DAN PEMBAHASAN}

A. Ketersediaan sarana prasarana perkuliahan dan layanan akademik

Standar minimal sarana dan prasarana perguruan tinggi mengacu pada rancangan standar sarana dan prasarana pendidikan tinggi yang ditetapkan melalui Peraturan Menteri Riset, Teknologi, dan Pendidikan Tinggi Republik Indonesia nomor 44 tahun 2015 tentang standar nasional pendidikan tinggi. Standar sarana dan prasarana pembelajaran merupakan kriteria minimal tentang sarana dan prasarana sesuai dengan kebutuhan isi dan proses pembelajaran dalam rangka pemenuhan capaian pembelajaran lulusan. Gambaran ketersediaan sarana dan prasarana di IAIN Palangka Raya adalah sebagai berikut.

\section{Ketersedian Sarana Perkuliahan dan} layanan akademik

a. Perabot

Perabot perkuliahan antara lain kursi untuk mahasiswa, kursi dosen dan meja dosen yang berada di ruang perkuliahan dan bertujuan menunjang kegiatan pendidikan secara tatap muka. IAIN Palangka Raya telah memiliki perabot perkuliahan yang lengkap. Setiap ruang kuliah sudah terisi dengan perabot kursi dan meja perkuliahan. Adapun rinciannya dapat dilihat pada Tabel 1.

Tabel 1 Perabot perkuliahan perfakultas

\begin{tabular}{lcc}
\hline $\begin{array}{c}\text { Fakultas/ } \\
\text { Program }\end{array}$ & \multicolumn{2}{c}{ Perabot } \\
\hline FEBI & 64 & $\begin{array}{c}\text { Kursi } \\
\text { Besi/Metal }\end{array}$ \\
\hline
\end{tabular}




\section{SULTANIST: Jurnal Manajemen dan Keuangan, Vol 9 (1), Juni 2021}

\begin{tabular}{lcc}
\hline MIPA & 10 & 104 \\
FTIK & 71 & 994 \\
FUAD & 64 & 474 \\
F. sya & 48 & 610 \\
Pasca & 52 & 248 \\
Jumlah & 308 & 3.308 \\
& \\
\hline \multicolumn{2}{l}{ Sumber: Sub Bagian Keuangan dan Barang Milik } \\
Negara (BMN) IAIN Palangka Raya
\end{tabular}

b. Peralatan Pendidikan

Peralatan pendidikan adalah bendabenda sebagai alat bantu dalam pendidikan atau segala perlengkapan yang dapat dipakai dalam usaha pendidikan yang tujuannya mempermudah dalam mencapai tujuan pendidikan (Hasbulah, 2009) seperti papan tulis, kapur tulis, spidol dan lain-lain. IAIN Palangka Raya setiap ruang kuliah dilengkapi dengan papan tulis, penghapus dan alat tulis berupa spidol. Selain itu dilengkapi juga dengan peralatan teknologi yang menunjang dalam proses pembelajaran, seperti LCD dan smart tv di setiap ruang perkuliahan.

c. Media Pendidikan;

Darajat (2011) menyebutkan pengertian alat pendidikan sama dengan media pendidikan sebagai sarana pendidikan. Termasuk alat berarti barang sesuatu yang dipakai untuk mencapai suatu maksud. Sedangkan media berasal dari bahasa latin dan bentuk jamak dari medium yang secara harfiah berarti perantara atau pengantar. Gegne yang dikutip oleh Ramayulis (2008) menyebutkan bahwa media adalah berbagai jenis komponen dalam lingkungan siswa yang dapat merangsang peserta didik untuk belajar. Sedangkan Brigs mendefinisikan media sebagai salah satu bentuk alat fisik yang dapat menyajikan pesan yang dapat merangsang siswa untuk belajar.
Ruang kuliah di IAIN Palangka Raya dilengkapi dengan media perkuliahan berupa LCD projector/infocus, layar projector dan monitor besar berupa smart TV. Smart tv ini bukan hanya dapat dipakai melalui laptop/PC, melainkan juga dapat dikoneksikan dengan smartphone. Tenaga pendidik maupun mahasiswa yang mau melakukan presentasi tidak harus memiliki laptop, namun cukup dikendalikan melalui HP pintar, meskipun tanpa harus mengunakan koneksi internet. Untuk ruang kuliah besar juga dilengkapi dengan 1 set pengeras suara. Table 2 menggambarkan tentang jumlah media pembelajaran di ruang kuliah yang dimiliki oleh sejumlah fakultas yang ada di IAIN palangka Raya

Tabel 2 Media Pendidikan per Fakultas

\begin{tabular}{|c|c|c|c|c|}
\hline \multirow{3}{*}{$\begin{array}{c}\text { Fakultas/ } \\
\text { Program }\end{array}$} & \multicolumn{4}{|c|}{ Media Pendidikan } \\
\hline & Televisi & LCD & Layar & White \\
\hline & & Projector & Film & Board \\
\hline FEBI & 15 & 10 & 2 & 21 \\
\hline MIPA & & 5 & & \\
\hline FTIK & 23 & 5 & 2 & 24 \\
\hline FUAD & 7 & 6 & 1 & 19 \\
\hline FSYA & 14 & 10 & 2 & 16 \\
\hline Pasca & 11 & 1 & & 7 \\
\hline Aula & & 2 & & \\
\hline Jumlah & 70 & 39 & 7 & 87 \\
\hline
\end{tabular}

d. Buku, buku elektronik, dan repositori;

Sarana pendidikan berupa buku yang dimiliki oleh IAIN Palangka Raya tersimpan di UPT Perpustakaan IAIN Palangka Raya. Jumlah buku yang terdapat di perpustakaan adalah 18. 946 judul dan 62.124 eksamplar. Sedangkan buku elektronik berjumlah 5.724 judul. Selain itu IAIN juga memiliki repository yang di kelola oleh perpustakaan dengan alamat http://digilib.iainpalangkaraya.ac.id/cgi/search/simple. (Profil Perpustakaan: 2020) 


\section{SULTANIST: Jurnal Manajemen dan Keuangan, Vol 9 (1), Juni 2021}

e. sarana teknologi informasi dan komunikasi;

IAIN Palangka Raya memiliki unit TIPD yang mengelola teknologi informasi di IAIN Palangka Raya seperti server, laboraturium computer dan jaringan bandwith yang dapat digunakan oleh lingkungan kampus yang kapasitasnya mencapai 50 Mbps. Jumlah 50 Mbps ini memang masih kurang, sehingga tiap fakultas, lembaga dan unit memiliki jaringan internet masing untuk menunjang aktifitas di kampus. Setiap kantor fakultas memiliki sejumlah computer dan laptop yang dilengkapi dengan printer, scanner. Setiap fakultas, lembaga dan unit juga memiliki website dan email.

Tabel 3 Teknologi informasi dan Komunikasi

\begin{tabular}{lccccc}
\hline \multicolumn{1}{c}{ Fakultas/ } & & \multicolumn{4}{c}{ Teknologi Informasi } \\
Program & PC & UPS & Printer & laptop & Scanner \\
FEBI & 7 & 4 & 7 & 0 & 0 \\
MIPA & 4 & 0 & 4 & 0 & 0 \\
FTIK & 13 & 0 & 16 & 1 & 0 \\
FUAD & 7 & 0 & 5 & 0 & 0 \\
FSYA & 5 & 0 & 9 & 1 & 0 \\
Pasca & 15 & 0 & 15 & 2 & 0 \\
TIPD & 77 & 4 & 3 & 0 & 1 \\
Lab. Bhs & 37 & 0 & 2 & 0 & 0 \\
Jumlah & 165 & 8 & 61 & 4 & 1 \\
\hline
\end{tabular}

Sumber: Sub Bagian Keuangan dan Barang Milik Negara (BMN) IAIN Palangka Raya

f. Instrumentasi Eksperimen

Untuk melakukan penelitian yang bersifat ekspremen, IAIN Palangka Raya dilengkapi dengan Laboraturium terpadu yang di dalamnya dilengkapi dengan alatalat yang dibutuhkan oleh setiap program studi. Selain itu untuk program studi biologi dilengkapi dengan rumah kaca yang tujuannya untuk meneliti tanaman herbal di Kalimantan Tengah.

g. Sarana Olahraga
Sarana olahraga yang tersedia di IAIN adalah Volley, Tenis meja, bola basket dan sepak bola.

h. Sarana Berkesenian

IAIN Palangka Raya menyediakan peralatan band music, alat drumband dan seragamnya, dan rebana untuk grup hadrah. Peralatan ini disediakan untuk civitas akademika yang minat dengan seni.

i. Sarana Fasilitas Umum

Sarana fasilitas umum yang tersedia di IAIN Palangka Raya antara lain adalah tempat parkir, kantin, gudang, pos satpam, penunjuk arah, mobil ambulans jenazah.

j. Bahan Habis Pakai

Bahan habis pakai yang tersedia antara lain adalah Alat Tulis Kantor, seperti kertas, polpen, tinta, gunting, cutter, dll.

k. sarana pemeliharaan, keselamatan, dan keamanan.

Sarana ini antara lain tabung alat pemadam api, namun ini tidak semua gedung tersedia. CCTV juga hanya perpustakaan yang menyediakan.

\section{Ketersediaan prasarana Perkuliahan dan layanan akademik}

a. Lahan

IAIN Palangka Raya memiliki lahan yang cukup luas yaitu sekitar 100 hektar, dengan 2 lokasi yang berbeda, 10 hektar sudah berdiri kampus di Jl. G. Obos komplek Islamic Center Palangka Raya dan 50 hektar lainnya masih berupa lahan yang berada di Jl. Yos Sudarso Palangka Raya. Lahan yang berada di G. Obos sebenarnya masih memungkinkan untuk dikembangkan dengan sejumlah bangunan, karena masih banyak tersedia lahan kosong di sekita bangunan kampus. 


\section{SULTANIST: Jurnal Manajemen dan Keuangan, Vol 9 (1), Juni 2021}

Kedua lahan ini statusnya sudah memiliki sertifikat kepemilikan oleh IAIN Palangka Raya. Lahan ini berada di lokasi yang nyaman dan aman untuk menunjang proses perkuliahan

b. Ruang kelas

Ruang kuliah yang dimiliki oleh IAIN Palangka Raya juga cukup luas dan banyak. Luas rata-rata setiap ruang kuliah berukuran $36 \mathrm{M}^{2}$. Setiap fakultas telah memiliki gedung khusus perkuliahan dengan rata-rata terdiri 15 ruangan. Gedung perkuliahan di IAIN Palangka Raya rata-rata terdiri dari 2 dan 3 lantai dengan luasan mulai dari 250 $\mathrm{m}^{2}$ hingga $2.214 \mathrm{~m}^{2}$. Gedung kuliah baru memiliki luasan lebih dari $900 \mathrm{~m}^{2}$, sedangkan Gedung kuliah lama memiliki luasan kurang dari $900 \mathrm{~m}^{2}$. Daftar gedung perkuliahan yang dimiliki IAIN Palangka Raya dapat dilihat dari Tabel 4. Luas Gedung Ruang Perkuliahan

Tabel 4 Luas Gedung Ruang

Perkuliahan

\begin{tabular}{ccrc}
\hline No & $\begin{array}{c}\text { Nama Gedung } \\
\text { Kuliah }\end{array}$ & $\begin{array}{c}\text { Luas } \\
\text { Gedung }\end{array}$ & Ket. \\
1. & Ged. kuliah A2 & $633 \mathrm{M}^{2}$ & 2 lantai \\
2. & Ged. Kuliah C1 & $250 \mathrm{M}^{2}$ & 2 lantai \\
3. & Ged. kuliah D1 & $300 \mathrm{M}^{2}$ & 2 lantai \\
4. & Ged. kuliah E2 & $715 \mathrm{M}^{2}$ & 2 lantai \\
5. & Ged. Kuliah D2 & $633 \mathrm{M}^{2}$ & 2 lantai \\
6. & Ged. Fak. TIK & $1,314 \mathrm{M}^{2}$ & 3 lantai \\
7. & Ged. Fak EBI & $2,214 \mathrm{M}^{2}$ & 3 lantai \\
8. & Ged. Fak. UAD & $2,214 \mathrm{M}^{2}$ & 3 lantai \\
9. & Ged. Fak Syariah & $2,214 \mathrm{M}^{2}$ & 3 lantai \\
10. & Ged. MIPA & $913 \mathrm{M}^{2}$ & 3 lantai \\
11. & Ged.Pascasarjana & $1,758 \mathrm{M}^{2}$ & 3 lantai \\
\hline Sumber: Sub Bagian & Keuangan dan \\
Barang Milik Negara & $(\mathrm{BMN})$ & IAIN \\
Palangka Raya &
\end{tabular}

c. Perpustakaan

IAIN Palangka Raya memiliki perpustakaan yang cukup representative dan terakreditasi B oleh Perpustakaan Nasional RI. Luas gedung perpustakaan adalah 1.653 $\mathrm{m}^{2}$ sebanyak 3 lantai. Perpustakaan IAIN
Palangka Raya saat ini dapat dikatakan sebagai perpustakaan terbesar di Palangka Raya. Perpustakaan IAIN Palangka Raya mulai dibangun pada tahun 2009 dan selesai untuk ditempati pada tahun 2011.
d. laboratorium/studio/bengkel kerja/unit produksi

Setiap fakultas di IAIN Palangka Raya memiliki laboraturium. Jumlah gedung laboraturium adalah sebanyak 6 buah dengan rincian sebagai berikut:

Tabel 5. Luas Gedung

Laboraturium

\begin{tabular}{llrr}
\hline No & $\begin{array}{c}\text { Nama Gedung } \\
\text { Laboraturium }\end{array}$ & \multicolumn{1}{c}{$\begin{array}{c}\text { Luas } \\
\text { Gedung }\end{array}$} & Ket. \\
1. & Lab. Eko. Syariah & $90 \mathrm{M}^{2}$ & 1 lantai \\
2. & Lab. Syariah & $173 \mathrm{M}^{2}$ & 1 lantai \\
3. & Lab. Terpadu & $2,597 \mathrm{M}^{2}$ & 3 lantai \\
4. & Lab. Biologi & $432 \mathrm{M}^{2}$ & 1 lantai \\
\hline
\end{tabular}

Sumber: Sub Bagian Keuangan dan Barang Milik Negara (BMN) IAIN Palangka Raya

e. Tempat berolahraga;

IAIN Palangka Raya memiliki lahan yang luas, sehingga masih banyak lahan yang memungkinkan untuk masyarakat kampus berolahraga. Ada sejumlah tempat olah raga yang sudah dibuat yaitu, lapangan basket, lapangan voly, dan lapangan terbuka yang dapat digunakan untuk bermain bola. Jalan yang ada di lingkungan kampus juga memungkinkan untuk dijadikan sarana berolahraga jogging atau lari yang tidak hanya digunakan oleh civitas akademika, namun juga oleh masyarakat sekitar kampus.

f. Ruang untuk berkesenian

Ruang berkesenian di IAIN Palangka Raya cukup memadai, meskipun tidak ada gedung secara khusus digunakan untuk gedung kesenian, namun sebagian ruang di 


\section{SULTANIST: Jurnal Manajemen dan Keuangan, Vol 9 (1), Juni 2021}

aula IAIN, maupun lahan kosong yang masih luas di IAIN Palangka Raya dapat digunakan mahasiswa untuk kegiatan berkesenian.

g. Ruang unit kegiatan mahasiswa

Ruang unit kegiatan mahasiswa juga disediakan di IAIN Palangka Raya, antara lain sanggar pramuka, markas resimen mahasiswa, PMR, dan secretariat untuk Himpunan Mahasiswa IAIN.

\section{h. Ruang pimpinan perguruan tinggi}

Ruang pimpinan perguruan tinggi terdiri dari beberapa gedung yaitu 1 buah gedung rektorat dan 4 gedung dekanat serta 1 gedung pascasarjana untuk direktur pascasarjana.

i. Ruang dosen

Ruang untuk dosen di IAIN Palangka Raya ada 2 gedung di samping gedung rektorat masing-masing luasnya $745 \mathrm{M}^{2}$

j. $\quad$ Ruang tata usaha

Ruang tata usaha di IAIN Palangka Raya juga ada pada gedung rektorat dan dekanat. Di rektorat ada Kabiro, Kabag Umum, Kabag Keuangan dan perencanaan beserta kasubag dan stafnya. Begitu juga pada gedung dekanat ada pimpinan struktural setingkat Kabag beserta kasubag dan stafnya untuk setiap fakultas.

k. Fasilitas umum yang meliputi

1) Jalan

IAIN Palangka Raya terletak di Jalan Raya G. Obos, satu komplek dengan masjid raya Darussalam. Ada 2 jalur jalan masuk pintu gerbang menuju kampus, jalur kiri dan jalur kanan, ditengahnya dibelah oleh trotoar yang ditanam dengan tanaman pelindung dan tanaman hias. Lebar jalan menuju kampus 20 meter.

2) air
Air yang tersedia di kampus IAIN adalah berasal dari air tanah yang disedot dengan mesin pompa air, setiap gedung memiliki sumber air tanah yang disedot dengan mesin pompa air

3) listrik

Semua gedung terpasang dengan aliran dan instalasi listrik. Listrik yang tersedia dari PLN. Hanya gedung rektorat yang mempunya sumber cadangan kelistrikan dari ginset.

4) jaringan komunikasi suara

Tidak semua gedung IAIN Palangka Raya terpasang jaringan komunikasi berupa telpon, namun jaringan yang dipasang untuk setiap gedung hanya penangkap signal wireless yang diambil dari gedung TIPD. Sedangkan jaringan telpon hanya pada gedung perkantoran.

5) data

IAIN data mempunyai pangkalan data yang dikelola oleh unit TIPD IAIN Palangka Raya.

1. Sarana dan prasarana lain yang dapat diakses oleh mahasiswa yang berkebutuhan khusus.

Permenristekdikti nomor 44 tahun 2015 tentang standar nasional pendidikan tinggi pada pasal 37 menyebutkan bahwa perguruan tinggi harus menyediakan sarana dan prasarana yang dapat diakses oleh mahasiswa yang berkebutuhan khusus yang meliputi:

1) Pelabelan dengan tulisan Braille dan informasi dalam bentuk suara;

2) Lerengan (ramp) untuk pengguna kursi roda;

3) Jalur pemandu (guiding block) di jalan atau koridor di lingkungan kampus;

4) Peta/denah kampus atau gedung dalam bentuk peta/denah timbul; dan 


\section{SULTANIST: Jurnal Manajemen dan Keuangan, Vol 9 (1), Juni 2021}

5) Toilet atau kamar mandi untuk pengguna kursi roda.

IAIN Palangka Raya untuk sarana prasarana yang dapat diakses oleh mahasiswa yang berkebutuhan khusus masih belum tersedia. Semua gedung yang dibangun tidak dirancang dengan memperhatikan keberadaan mahasiswa berkebutuhan khusus. Begitupula dengan informasi, peta atau jalur pemandu yang ada di kampus, semuanya tidak ada yang ditulis dalam bentuk huruf timbul. Padahal sejak tahun 2017 sudah ada mahasiswa di IAIN yang termasuk kategori berkebutuhan khusus, meskipun jumlahnya hanya 1 orang. Sehingga saat perkuliahan mahasiswa tersebut dibantu oleh teman-temannya diangkat beserta kursi rodanya masuk ruang kuliah.

\section{B. Kelayakan sarana prasarana perkuliahan dan layanan akademik}

Data tentang kelayakan sarana prasarana perkuliahan menurut persepsi civitas akademika didapatkan dari penyebaran angket dengan civitas akademika dari berbagai fakultas, Pascasarjana, unit lembaga dan UPT serta Mahasiswa dan alumni. Adapun sarana dan prasarana yang diminta untuk diberikan responnya oleh responden adalah meliputi laboraturium, teknologi informasi, perabot perkuliahan, rasio ketersediaan ruang kuliah, rasio ketersediaan lahan, ketersediaan sarana prasarana untuk mahasiswa berkebutuhan khsusus, layanan akademik, perpustakaan, ruang dosen, ruang pimpinan, ruang unit kegiatan mahasiswa dan fasilitas umum. Hasil angket tersebut dapat dilihat pada Tabel 6

Tabel 6 Kelayakan Sarana dan Prasarana

IAIN Palangka Raya

\begin{tabular}{|c|c|c|c|c|c|}
\hline No & $\begin{array}{c}\text { Jenis Sarana } \\
\text { dan } \\
\text { Prasarana }\end{array}$ & $\mathrm{TL}$ & $\mathrm{KL}$ & $\mathrm{L}$ & SL \\
\hline 1 & Laboraturium & 6.27 & 19.85 & 56.65 & 20.37 \\
\hline 2 & $\begin{array}{l}\text { Teknologi } \\
\text { informasi }\end{array}$ & 0.00 & 7.14 & 85.71 & 7.15 \\
\hline 3 & $\begin{array}{l}\text { sarana } \\
\text { perkuliahaan }\end{array}$ & 0.00 & 10.72 & 76.19 & 16.67 \\
\hline 4 & Lahan IAIN & 0.00 & 7.14 & 57.14 & 35.72 \\
\hline 5 & Ruang kelas & 0.00 & 7.14 & 71.43 & 21.43 \\
\hline 6 & $\begin{array}{l}\text { Sarpras } \\
\text { Penyandang } \\
\text { disabilitas }\end{array}$ & 19.05 & $\begin{array}{c}75.71 \\
2\end{array}$ & 21.43 & 0.00 \\
\hline 7 & Toilet & 0.00 & 25.45 & 65.75 & 8.8 \\
\hline 8 & Perpustakaan & 0.00 & 8.33 & 55.41 & 36.26 \\
\hline 9 & Ruang dosen & 0.00 & 14.29 & 71.43 & 14.28 \\
\hline 10 & $\begin{array}{l}\text { Ruang } \\
\text { perkantoran }\end{array}$ & 0.00 & 12.1 & 84.37 & 11.59 \\
\hline 11 & $\begin{array}{l}\text { Sarana } \\
\text { olahraga }\end{array}$ & 0.00 & 39.29 & 50.00 & 21.43 \\
\hline 12 & $\begin{array}{l}\text { operasional } \\
\text { pembelajaran }\end{array}$ & 0.00 & 14.29 & 78.57 & 7.14 \\
\hline 13 & $\begin{array}{l}\text { Barang habis } \\
\text { pakai }\end{array}$ & 0.00 & 14.29 & 78.57 & 7.14 \\
\hline 14 & $\begin{array}{l}\text { Alat } \\
\text { keselamatan }\end{array}$ & 0.00 & 35.71 & 50 & 14.29 \\
\hline 15 & Sarana parkir & 0.00 & 71.43 & 28.57 & 0.00 \\
\hline 16 & $\begin{array}{l}\text { Fasilitas } \\
\text { umum (arus } \\
\text { listrik, air, } \\
\text { toilet dan } \\
\text { jaringan } \\
\text { komunikasi } \\
\text { suara dan } \\
\text { data) }\end{array}$ & 0.00 & 14.29 & 71.43 & 14.28 \\
\hline & ata-rata & 12.66 & 23.5 & 62.67 & 16.90 \\
\hline
\end{tabular}

Keterangan: Tidak Layak (TL), Kurang Layak (KL), Layak (L), Sangat Layak (SL)

Tabel 6 menujukkan kelayakan sarana prasarana perkuliahan dan layanan akademik IAIN Palangka Raya sudah terkategori Layak $62,67 \%$ dan $16,90 \%$ sangat layak. Hal ini menujukkan sarana dan prasarana perkuliahan dan pelayanan akademik di IAIN Palangka Raya baik dan memenuhi standar. Ketersediaan sarana dan praarana yang sudah layak ini diharapkan dapat menujang keberhasilan program perkuliahan dan layanan akdemik di IAIN 


\section{SULTANIST: Jurnal Manajemen dan Keuangan, Vol 9 (1), Juni 2021}

Palangka Raya. Hal ini sejalan dengan pernyataan Pahlevi (2016) bahwa keberhasilan program pendidikan melalui proses belajar mengajar dipengaruhi faktor tersedianya sarana dan prasarana pendidikan yang memadai.

Berdasarkan Tabel 6, terdapat penilaian tidak layak sebesar $19,5 \%$ pada aspek sarana prasarana penyandang disabilitas. Hal ini perlu menjadi sorotan mengingat IAIN Palangka Raya memiliki mahasiswa penyandang disabilitas, mesikipun jumlahnya masih sedikit. Keberadaan disabilitas menjadi perhatian tersendiri bagi negara Republik Indonesia bahkan dunia saat ini, hal ini ditunjukkan dengan adanya Undang-Undang Nomor 19 Tahun 2011 tentang pengesahan convention on the rights of persons with disabilities (konvensi mengenai hak-hak penyandang disabilitas). Dalam pasal 2 dinyatakan Akomodasi yang beralasan" berarti modifikasi dan penyesuaian yang perlu dan sesuai, dengan tidak memberikan beban tambahan yang tidak proporsional atau tidak semestinya, apabila diperlukan dalam kasus tertentu, guna menjamin penikmatan ataupelaksanaan semua hak asasi manusia dan kebebasan fundamental penyandang disabilitasberdasarkan kesetaraan dengan yang lainnya

Seiring dengan hal tersebut, akses dan fasilitas umum yang ramah bagi penyandang disabilitas dibangun di beberapa fasilitas umum tak terkecuali pada lembaga Pendidikan seperti di IAIN Palangka Raya. Namun pembangunan fasilitas tersebut dirasa belum maksimal mengingat hasil responden yang menyatakan beberapa indikator ketersediaan fasilitas bagi difabel tersebut dinyatakan belum layak.
Ketersedian informasi dengan bentuk pelabelan dengan tulisan braille dan informasi dalam bentuk suara belum sepenuhnya maksimal. Tulisan bralille hanya terdapat di gedung perpustakaan dan belum dapat dijumpai di sebagian besar gedung yang ada di IAIN Palangka Raya. Kondisi seperti ini harusnya menjadi pertimbangan tersendiri bagi pemenuhan kebutuhan sarana dan prasarana di kampus hijau tersebut.

Akses bagi disabilitas dalam memperoleh pendidikan juga tercermin pada keberadaan ketersedian lerengan (ramp) untuk pengguna kursi roda. Keberadaan lereng tersebut tidak layak mengingat beberapa gedung utama sebagai tempat pelayanan seperti rektorat, mikwa dan gedung bertingkat lainnya belum memiliki akses untuk jalannya kursi roda. Keberadaan gedung-gedung dengan usia yang sudah tua tidak mempertimbangkan pembangunan akses bagi disabilitas, berbeda halnya dengan gedung-gedung terbaru yang sebagian besar sudah memenuhi standar tersebut. Pendapat yang menyatakan akses untuk penyandang disabilitas sudah layak didasarkan pada keberadaan lereng yang ada pada gedung-gedung baru seperti gedung pascasarjana yang sudah sangat nyaman untuk jalannya kursi roda.

Fasilitas lain bagi disabilitas yang tak kalah penting adalah Jalur pemandu (guiding block) di jalan atau koridor di lingkungan kampus. salah satu tampilan yang berbeda pada fasilitas umum sekarang ini adalah dengan adanya ubin dengan tekstur titik dan garis panjang yang terdapat pada trotoar. Ubin-ubin tersebut dinamakan Guiding Block. Guiding Block dengan fungsi membantu mengarahkan pejalan kaki yang memiliki kebutuhan khusus terutama 


\section{SULTANIST: Jurnal Manajemen dan Keuangan, Vol 9 (1), Juni 2021}

bagi penyandang tunanetra. Hampir tidak ada lantai semen atau batu yang berbeda warna yang bisa dilewati kursi roda untuk menuju bangunan tertentu. Kebanyakan lantai halaman gedung hanya berupa semen yang sedikit di selingi dengan batu kerikil. Tidak adanya Guiding Block di sekitar area kampus menjadikan kondisi tersebut tidak layak terhadap kebutuhan bagi tunanetra tersebut.

Kebutuhan lain bagi penyandang disabilitas yang harus dipenuhi adalah toilet bagi pengguna kursi roda. Karakteristik toilet bagi pengguna kursi roda sesuai dengan Permendikti No 44 Tahun 2015 antara lain:

a. Memiliki ruangan yang lebih luas

b. Pintu dibuat dalam bentuk geser untuk memudahkan membuka serta menutup

c. Lantai dalam kondisi kasar, hal ini bertujuan agar pengguna kursi roda tidak mudah tergelincir di lantai yang licin

d. Ketersediaan tombol darurat untuk menjaga keamanan jika ada insiden yang tak diinginkan

e. Handrail, merupakan pegangan tangan yang dapat digunakan bagi pengguna kursi roda saat mau duduk maupun berdiri

f. Ketinggian toilet menyesuaikan dengan rata-rata ketinggian kursi roda

IAIN Palangka Raya saat ini belum memiliki fasilitas tolet bagi penyandang disabilitas. Hal tersebut menjadikan mayoritas responden berpendapat bahwa toilet untuk pengguna kursi roda kurang layak bahkan tidak layak. Toilet uang ada saat ini mayoritas WC jongkok dan hanya beberapa toilet yang menggunakan WC duduk yang belum memenuhi kriteria diatas..

\section{SIMPULAN DAN SARAN}

Berdasarkan hasil dan pembahasan penelitian dapat disimpulkan Sebagian besar sarana dan prasarana yang ada di IAIN Palangka Raya yang tersebar di berbagai fakultas dan unit lembaga telah memeliki ketersediaan yang mencukupi dan layak untuk dipergunakan. sarana dan prasarana tersebut memiliki rasio sesuai dengan karakteristik metode dan bentuk pembelajaran, serta menjamin terselenggaranya proses pembelajaran dan pelayanan administrasi akademik sebagaimana tertuang dalam Peraturan Menteri Riset, Teknologi, dan Pendidikan Tinggi Republik Indonesia nomor 44 tahun 2015. Namun masih terdapat beberapa sarana dan prasarana yang belum layak terutama sarana dan prasarana bagi penyandang disabilitas, masih sangat minim fasilitas bagi penyandang disabilitas yang merupakan amanah dari Permen Ristek Dikti tersebut. Kebutuhan penambahan sarana dan prasarana dalam rangka memperclancar terlaksananya kegiatan belajar mengajar maupun kegiatan layanan akademnik terbagi ke dalam dua kelompok, yaitu kebutuhan sarana jenis meubelair serta kebutuhan sarana dalam bentuk elektronik.

\section{DAFTAR PUSTAKA}

Abbas, Syahrizal, 2008, Manajemen Perguruan Tinggi, Jakarta: Kencana Prenada Media

Bafadal, I. 2003, Manajemen Sarana dan Prasarana Pendidikan. Dalam Imron,A A., Maisyaroh, dan Burhanuddin (eds.), Manajemen Pendidikan: Analisis Suabtantif dan Aplikasinya dalam latar institusi pendidikan ( hlm. 85-89). Malang : Penerbit Universitas Negeri Malang. 
Barnawi, dan Arifin, M.2012, Manajemen Sarana dan Prasarana Sekolah. Yogyakarta: Ar-Ruz Media.

Darajat, Zakiyah, Ilmu Pendidikan Islam, Jakarta: Bumi Aksara,2011.

Depdiknas, 2008. Administrasi dan pengelolaan Sekolah. Jakarta: Direktorat Tenaga Kependidikan, Direktorat Jenderal PMPTK, Depdiknas.

$$
\text { 2009, Manajemen }
$$

Pembelajaran Kelas. Jakarta: BP. Dharma Bhakti

Gaspersz, V. 2005. Total Quality Management. Jakarta: Gramei Pustaka Utama.

Gunawan, Imam dan Djum Djum Noor Benty, 2017, Manajemen Pendidikan, Alfabeta: Bandung.

Hasbullah. 2009. Dasar - Dasar Ilmu Pendidikan. Jakarta: Raja grafindo Persada.

Indrajit, Eko \& Djokopranoto, 2006, Manajemen Perguruan Tinggi Modern, Yogyakarta: Andi Ofset

Mustari, M.2014. Manajemen Pendidikan. Jakarta: Raja Grafindo

Matin, 2013, Dasar-dasar perencanaan pendidikan, Jakarta: Raja Grafindo Persada.

Matin dan Nurhattati Fuad, 2016, Manajemen Sarana dan Prasarana Pendidikan Konsep dan Aplikasi, Jakarta: Raja Grafindo Persada

Paraturan Menteri Agama Nomor 8 Tahun 2015 Tentang Organisasi dan Tata Kerja Institut Agama Islam Negeri Palangka Raya

Peraturan Menteri Agama Nomor 62 Tahun 2017 Tentang Perubahan atas Peraturan Menteri Agama Nomor 8 Tahun 2015 Tentang Organisasi dan Tata Kerja Institut Agama Islam Negeri Palangkaraya
Peraturan Menteri Keuangan Republik Indonesia Nomor 102/PMK.02/2018 tentang klasifikasi anggaran

Peraturan Menteri Keuangan Republik Indonesia Nomor 181/PMK.06/2016 tentang Penatausahaan Barang Milik Negara

Peraturan Menteri Riset, Teknologi, dan Pendidikan Tinggi Republik Indonesia Nomor 44 Tahun 2015 Tentang Standar Nasional Pendidikan Tinggi

Perpres No. 16 tahun 2018 tentang Pengadaan Barang dan Jasa Pemerintah

Pahlevi, R., Imron, A., \& Kusumaningrum, D. E. (2016). Manajemen saranan dan prasarana untuk meningkatkan mutu penbelajaran. Manajemen Pendidikan, 25(1), 88-94.

Megasari, R. (2020). Peningkatan pengelolaan sarana dan prasarana pendidikan untuk meningkatan kualitas pembelajaran di SMPN 5 Bukittinggi. Jurnal Bahana Manajemen Pendidikan, 2(1), 636648.

Sunandar, A.2013. Efektivitas Keberadaan Komite Sekolah Untuk Peningkatan Mutu Layanan Sekolah. Universitas Negeri Malang.

Setyaningih, S. (2019). Pengelolaan Sarana Prasarana dalam Implementasi Kurikulum Pendidikan Guru Sekolah Dasar: Sebuah Studi Kasus di Universitas Negeri

Semarang. Manajemen

Pendidikan, 13(2), 62-71.

\section{PROFIL SINGKAT}

Ibnu Hasan Karbila, lahir pada tanggal 06 Juni 1987 di Nganjuk, Jawa Timur. Telah menyelesaikan study S1 pada tahun 2011 dan saat ini tercatat sebagai mahasiswa Prodi Ekonomi Syariah Pascasarjana IAIN Palangka Raya. Aktivitas sehari-hari 
melaksanakan tugas sebagai Fungsional Peencana Pertama di bidang Perencanaan Anggaran IAIN Palangka Raya.

Usman, lahir pada tanggal 09 September 1971 di Negara HSS Kalimantan Selatan. Pendidikan terakhir yang diselesaikan adalah S2 Filsafat Hukum Islam pada tahun
2008. Pernah studi S1 jurusan Ilmu Pepustakaan di UI dan lulus tahun 1999. Sekarang aktifitasnya sebagai kepala UPT Perpustakaan di IAIN Palangka Raya sejak tahun 2003 hingga sekarang 